\title{
Un acercamiento teórico-metodológico para la enseñanza de estrategias lingüísticas orientadas a la lectoescritura en el aula de Español como Lengua Extranjera y Disciplinar
}

\author{
Estela Mattioli ${ }^{(1)}$ y Analía Demarchi ${ }^{(2)}$
}

Palabras clave. didáctica - español como lengua extranjera · estrategias lingüísticas · Lingüística Sistémico Funcional

Resumen. En este trabajo se presentan avances de un proyecto de investigación centrado en la elaboración de una propuesta didáctica para docentes dedicados a la enseñanza de español como lengua segunda o extranjera en general (ELSE) y, particularmente, para aqueIlos que realizan esta tarea con estudiantes brasileños. El objetivo es aportar algunos fundamentos teóricos y metodológicos acerca de la implementación de estrategias lingüísticas contrastivas aplicadas a la escritura e interpretación de explicaciones científicas en el aula de ELEyD (enseñanza de español como lengua extranjera y disciplinar).

La investigación se focaliza en el análisis lingüístico gramatical de diversos textos producidos por expertos y novatos, dentro del marco de la Lingüística Sistémica Funcional complementada con aportes de otros campos que posibiliten sustentar conexiones entre aspectos lingüístico-gramaticales, sociosemánticos y cognitivos del lenguaje.

(1) Docente responsable de Comunicación Oral y Escrita en las carreras de Ingeniería de la Facultad de Ingeniería y Ciencias Hídricas (FICH) de UNL, del Taller de Tesis en la Maestría en Ingeniería de los Recursos Hídricos de FICH-UNL y del Seminario Desarrollo de Competencias Académicas de la Licenciatura en Español como Lengua

Keywords. didactics - Spanish as a foreign language $\cdot$ language strategies $\cdot$ Systemic Functional Linguistic

Abstract. In this work we present advances of a research project focused on the development of a teaching proposal for teachers dedicated to teaching Spanish as a second and foreign language in general (ELSE) and, particularly, for those who perform this task with Brazilian students.

The objective is to provide some theoretical and methodological bases about the deployment of contrasting linguistic strategies applied to the writing and interpretation of scientific explanations in the classroom of ELEyD (teaching of Spanish as a foreign language and discipline).

The research focuses on the grammatical linguistic analysis of various texts produced by experts and novices, within the framework of the Systemic Functional Linguistics supplemented by contributions from other fields that make possible to sustain connections between linguistic-grammatical, social semantic and cognitive aspects of the language.

Segunda o Extranjera de la Facultad de Humanidades y Ciencias de la UNL. Contacto: emattiol@unl.edu.ar

(2) Docente de Comunicación

Oral y Escrita y de Proyecto
Final de Carrera de FICH-UNL. Contacto: analiademarchi2000@yahoo. com.ar 